УДК 656.025 .2

UDC 656.025.2

Хітров I.О., Сорока В.С., Кристопчук М.С., Пашкевич С.М.

Національний університет водного господарства та природокористування

\title{
МОДЕЛЬ ФОРМУВАННЯ ПЛОЩІ ТРАНСПОРТНОГО ОБСЛУГОВУВАННЯ МАРШРУТІВ ПАСАЖИРСЬКОГО СПОЛУЧЕННЯ
}

Одним 3 методів, що дозволяють оцінювати ефективність функціонування пасажирської транспортної системи приміського сполучення на етапі проектування маршрутної мережі i удосконалення діючої є моделювання іiі роботи. Цей процес може бути виконаний за допомогою апарату математичного моделювання. Застосування останнього для оцінки наслідків впровадження змін у маршрутній мережі пасажирського сполучення становить значний інтерес внаслідок таких причин: на даний час розроблено досить повний математичний апарат, що дозволяє здійснювати необхідну модифікацію існуючих моделей, і враховує специфіку конкретної маршрутної мережі; використання математичних моделей не вимагає значних ресурсів $\mathrm{i}$ дає можливість легко їх реалізувати на практиці 3 використанням EOM, що дозволяє при необхідності проводити багаторазовий аналіз у процесі проектування та експлуатації мережі; математичні моделі, на відміну від натурного моделювання, вимірювання та статистичного аналізу параметрів реальної маршрутної мережі пасажирського сполучення (у випадку, якщо маршрутна мережа уже спроектована i знаходиться в процесі експлуатації), дозволяють робити висновки про тенденції розвитку мережі, що $€$ важливим при дослідженні транспортної системи пасажирського сполучення.

Необхідні передумовами вирішення поставлених завдань у загальному вигляді визначаються параметрами попереднього їх опису, територіального розміщення вузлів, елементів системи на аналізованому ринку транспортного обслуговування, між якими формуються зв'язки різного роду, що вимагають кількісної оцінки реалізацій відповідно до висунутих потреб на транспортні послуги. Умови достатності встановлюють методи, алгоритм вирішення завдань визначення кількісних характеристик оптимальних транспортних процесів і зв'язків. Їх характеристики повинні враховувати нормативи обмежень забезпечення надійності, безпеки, доцільності, ефективності, інші специфічні умови функціонування систем.

У роботі пропонується удосконалений метод прогнозування потенціалу транспортних послуг, що може бути застосований при моделюванні функціонування транспортної системи пасажирського сполучення.

Ключові слова: пасажирська транспортна система, приміське сполучення, площа транспортного обслуговування, маршрутна мережа, ринок транспортних послуг.

\section{ВСТУП}

Існуючі проблеми, що стримують забезпечення зростаючого за обсягами і якістю попиту на транспортні послуги, визначають необхідність здійснення комплексу організаційно-правових, економічних і техніко-технологічних заходів, розрахованих як на близьку, так і на довгострокову перспективу, що забезпечать розвиток транспортного комплексу для сприяння розвитку продуктивних сил країни, соціальної мобільності населення, надійності транспортної системи [1-3].

Труднощі формалізації процесів і закономірностей формування потоків вимог на перевезення стали серйозною причиною відставання результатів наукових досліджень від вимог практики. Якщо не враховувати закономірності розвитку транспортної мережі, розподіл завантаження ії ділянок, то це призведе до перевантаження (недовантаження) окремих ліній і вузлів мережі, підвищення рівня аварійності, негативних екологічних наслідків.

\section{АНАЛІЗ ЛІТЕРАТУРНИХ ДАНИХ ТА ПОСТАНОВКА ПРОБЛЕМИ}

У даний час накопичено великий досвід при моделюванні транспортних систем, проведені комплексні дослідження транспортних систем пасажирського сполучення автомобільним транспортом, результати яких представлені в наукових працях зарубіжних і вітчизняних вчених. Зокрема, критерії для оцінки ефективності функціонування транспортних систем докладно описані в $[1-3,5]$.

Методи проектування транспортних систем знайшли своє відображення в роботах Я. Вандаса, А. Фішера, О.К. Кудрявцева, М.С. Крамара (статичні моделі) [1] та Л.А. Яковлєва, Ю.С. Кірзнера 
(динамічні моделі) [1]. Недоліком статичних моделей є те, що вони оптимізують транспортну систему відносно випадкового розселення, в результаті чого розрахункові транспортні навантаження можуть суттєво відрізнятись від фактичних.

Динамічні моделі (модель Л.А. Яковлєва) враховують зміни в транспортній системі пов'язані 3 факторами "розселення - тяжіння", але не забезпечують однозначного алгоритму пошуку ії структури $[1,3]$.

Відомі підходи, в яких автори $[4,6]$ розглядають розподіл поїздок за законом Пуассона, та відзначають багатофакторність моделі формування пасажирських кореспонденцій, а отже i рухливості населення, та пропонують використовувати принцип максимізації ентропії [5].

3 метою побудови ефективної мережі громадського пасажирського транспорту з урахуванням попиту на пересування, автори [6] використовують аналіз альтернативних поїздок за принципом Парето-оптимальності.

Енергоентропійний метод у різних сферах з успіхом розробляли такі вчені, як Больцман Л., Бриллюен Л., Вінер Н. та інші, у задачах управління Абдєєв Р.Ф., Куликов А.В. Ентропійний підхід для вирішення транспортних проблем [7] був уперше застосований Вільсоном у 1967 р. і пізніше часто використовувався при вирішенні транспортних завдань (вибір місця призначення, виду транспорту, маршруту пересування). В ентропійному аналізі люди (пасажири) уподібнюються молекулам газу і діють в каналізованому броунівському русі незалежно один від одного. Ентропійні моделі таких складних об'єктів, як міжміські й регіональні пасажирські транспортні системи дозволяють одержувати близькі до реальних дані про досліджувані процеси.

Однією 3 відправних точок для вирішення ряду проблем, пов'язаних з побудовою моделі, $\epsilon$ завдання визначення пасажиропотоків. Регіон являє собою складну багатоелементну і неоднорідну динамічну систему. Регіональні транспортні системи характеризуються істотною різнорідністю i неповнотою інформації про процеси, що в них протікають. У зв'язку з неповнотою інформації, одним 3 можливих методів визначення пасажиропотоків, є гравітаційний. Використання гравітаційної моделі наявне в роботах багатьох авторів [3-6], причому в багатьох випадках вона зазнає деяких змін у плані застосування функції тяжіння, в якості якої можуть бути запропоновані як витрати на пересування пасажирів між районами, так і затрати часу на їх переміщення та інші функціонали. Крім того, в кожному конкретному випадку треба проводити адаптацію моделі шляхом введення калібрувальних коефіцієнтів, що залежать від параметрів моделі.

Гравітаційні моделі є наслідком класичної термодинамічної моделі максимізації ентропії $[5,7]$. Метод максимізації ентропії, по суті, приписує рівні ймовірності всім станам складної системи, що не виключаються апріорною інформацією.

Принципи ринкової економіки формують нову формулу індивідуального вибору споживачем обсягу і виду транспортних послуг, тому на етапі вибору й побудови моделі функціонування транспортної системи особливу увагу слід приділити відповідності прийнятої гіпотези про протікання процесів пасажирообміну в системі, вибору вузлів зародження та погашення пасажиропотоків, визначитися 3 критерієм ефективності системи. 3 цією метою треба провести грунтовний аналіз відомих моделей транспортних процесів і побудови транспортних систем, провести їх адаптацію для дослідження транспортної системи приміського пасажирського сполучення, формування ринку транспортних послуг з урахуванням площі транспортного обслуговування маршрутів пасажирського сполучення.

\section{ЦІЛЬ ТА ЗАДАЧІ ДОСЛІДЖЕННЯ}

Аналіз ринку пасажирських транспортних послуг у приміському сполученні, в умовах зростання транспортної рухомості населення, вимагає чіткої сегментації з метою забезпечення врахування інтересів суб'єктів перевізного процесу, комфортності й безпеки пересування шляхом оптимізації структури й кількості транспортних засобів які обслуговують маршрутну мережу, на основі вивчення провізних можливостей маршрутів. Найбільш прийнятним для моделювання пасажиропотоків по мережі $є$ гравітаційний підхід. При цьому необхідним $є$ встановлення закономірностей розселення жителів по території, які на даний час вивчений не достатньо. Тому слід провести дослідження вказаного параметра й виявити залежності його зміни від просторового розміщення населених пунктів відносно обласного чи районного центрів. Тому важливим завданням дослідження $\epsilon$ побудова моделі розрахунку потенціалу транспортних послуг у приміському сполученні та розробка методу розрахунку потенціалу транспортних послуг у приміському сполученні, на основі площі транспортного обслуговування маршрутів.

\section{РЕЗУЛЬТАТИ ДОСЛІДЖЕНЬ}

При формуванні критерію ефективності пасажирської транспортної системи приміського 
пасажирського сполучення слід мати на увазі, що аналіз статистичних даних стосовно функціонування маршрутної мережі пасажирського сполучення (кількість одиниць рухомого складу i його техніко-експлуатаційні показники, обсяги перевезених пасажирів) не можуть повною мірою відповісти на питання: наскільки оптимальна маршрутна мережа, наскільки транспорт задовольняє потреби населення в перевезеннях, як при наявній транспортній системі оцінити рівень обслуговування населення.

Тому, доцільно провести поділ показників у групи, які відображають економічну та соціальну складові ефективності, що в свою чергу дозволить вирішити проблему поєднання інтересів пасажирів і транспортних підприємств із суспільними, яка виникає через вплив наступних факторів [1,9]:

- транспортної рухомості населення;

- провізної здатності пасажирського громадського транспорту (типу і чисельності рухомого складу);

- рівня організації пасажирських перевезень.

Інтереси транспортних підприємств (перевізників) відображають рівень доходної частини та забезпечення прибуткової роботи при обслуговуванні пасажирів.

В свою чергу, інтереси пасажирів зводяться до мінімізації витрат часу і коштів на поїздки, підвищенні безпеки i комфорту під час користування транспортом, що відображає соціальну складову ефективності пасажирської транспортної системи приміського сполучення. Поєднання інтересів пасажирів і перевізників характеризують суспільні інтереси: задоволення соціальних вимог населення; забезпечення рентабельності роботи транспортних підприємств; мінімізація шкідливого впливу на здоров'я і продуктивність праці членів суспільства; мінімізація шкідливого впливу транспорту на навколишнє природне середовище.

Цільова функція для дослідження ефективності пасажирської транспортної системи приміського сполучення, описується залежністю виду

$$
E=\frac{\sum_{i=1}^{n}\left(Q_{i}(A, g) \cdot T_{i}\right)-\sum_{i=1}^{n}\left(T_{H} \cdot A \cdot R_{O}(A, g) \cdot\left(C_{3 M}(A, g) \cdot L_{i}(A, g)+C_{n o c m}(A, g) \cdot \frac{L_{i}(A, g)}{V_{e}}\right)\right)}{\sum_{i=1}^{n}\left(T_{H} \cdot A \cdot R_{o}(A, g) \cdot\left(C_{3 M}(A, g) \cdot L_{i}(A, g)+C_{n o c m}(A, g) \cdot \frac{L_{i}(A, g)}{V_{e}}\right)\right)} \rightarrow \underset{A, g \in \Omega}{\max },
$$

при обмеженнях $\Omega$ :

$$
\begin{aligned}
& A, g>0 ; \\
& A, g=i n t ; \\
& \sum_{i=1}^{n} Q_{i}(A, g)=\sum_{k=1}^{N_{\max }} \sum_{l=1}^{N_{\max }} H_{k l} ; \\
& \sum_{i=1}^{n} L_{i}(A, g)=L_{M M},
\end{aligned}
$$

де $E$ - ефективність пасажирської транспортної системи приміського сполучення, грн./грн.;

$Q_{i}(A, g)$ - обсяг перевезень на $i$-му маршруті за розрахунковий період, пас.;

$T_{i}$ - тариф на маршруті, грн.;

$T_{H}$ - тривалість розрахункового періоду, год.;

$A$ - кількість транспортних засобів на маршрутах приміського сполучення, од.;

$g$ - пасажиромісткість транспортного засобу, задіяного на перевезеннях пасажирів, од.;

$R_{o}(A, g)$ - кількість оборотних рейсів за розрахунковий період;

$C_{3 м}(A, g)$ - складова змінних витрат, грн./км;

$C_{\text {nост }}(A, g)$ - складова постійних витрат, грн./год.;

$L_{i}(A, g)$ - довжина $i$-го маршруту, км;

$V_{e}$ - експлуатаційна швидкість, км/год.;

$H_{k l}$ - максимальна сумарна реалізована кореспонденція пасажирів з $k$-го населеного пункту в $l$-й за розрахунковий період, пас.; 
$L_{M M}$ - сумарна довжина маршрутної мережі при охопленні максимальної кількості населених пунктів приміським сполученням, км;

$n$ - кількість маршрутів сполучення;

$N_{\text {max }}$ - максимальна кількість населених пунктів, охоплених транспортним сполученням.

Таким чином, ефективність транспортної системи пасажирського сполучення відображає рентабельність перевезень, і є складовою економічної ефективності.

Забезпечення соціальної складової ефективності транспортної системи пасажирського сполучення закладено в обмеженнях, а саме: сумарні реалізовані кореспонденції між населеними пунктами, що включені до пасажирської транспортної системи приміського сполучення досягають максимального значення при повному охопленні населених пунктів транспортним сполученням. Це можливо при збільшенні сумарної довжини маршрутної мережі пасажирського сполучення. Дотримання соціальних нормативів транспортного обслуговування населення, встановлених державними органами влади, знижує економічну складову ефективності, що вимагає встановлення оптимальної структури парку для транспортного обслуговування населення. Змінною, яка регулює структуру парку транспортних засобів, доцільно прийняти кількість пасажиромісць в транспортній системі пасажирського сполучення.

Слід відмітити, що попит на транспортні послуги визначається не тільки чисельністю, складом і розподілом населення по території, але й змінами рівня його добробуту, зайнятості, перебудовою системи транспортного обслуговування в сучасних умовах, проявом дії закономірностей зміни індивідуальних можливостей та потреб $[4,8,9,11]$. Одночасно з цим відбувається перерозподіл у характері переваг, концентрації і виборі напрямків поїздок жителів конкретного регіону, трудові поїздки перерозподілилися з виробничої сфери в посередницьку, проходить зміна положення центрів зародження і погашення поїздок на території регіону. Таким чином, розроблені раніше алгоритми моделювання маршрутної мережі пасажирського сполучення морально застаріли й не можуть бути повною мірою використані для опису процесу переміщення пасажирів у сучасних умовах.

Модель функціонування транспортної системи пасажирського сполучення умовно складається 3 моделі транспортної мережі, моделі потреби в пересуваннях, моделі маршрутної мережі й моделі розподілу пасажиропотоків. Визначальним етапом у процесі моделювання транспортної системи пасажирського сполучення є модель маршрутної мережі. Ця модель являє собою траси маршрутів та їхніх провізних можливостей. Ці параметри визначають показники ефективності транспортної системи пасажирського сполучення.

Модель транспортної мережі подана у вигляді математичного опису елементів транспортної мережі пасажирського сполучення в регіоні, по яких можливий рух транспортних засобів громадського користування $[10,12]$.

Модель потреб у переміщеннях являє собою матрицю міжрайонних кореспонденцій пасажирів, що в подальшому трансформується в матрицю міжзупинних кореспонденцій на основі трас маршрутів мережі. Одержання цієї матриці доцільно проводити 3 використанням гравітаційного методу розрахунку кореспонденцій. У цьому випадку в якості вихідних даних виступає ємність транспортних районів регіону й матриця найкоротших відстаней, визначена на основі математичного опису транспортної мережі.

Модель маршрутної мережі складається з трас маршрутів і кількості транспортних засобів. Для забезпечення ефективної роботи транспортної системи пасажирського сполучення у цілому необхідно зв'язати параметри геометрії трас маршрутів і пасажиропотоки на цих маршрутах. 3 цією метою використовується модель перерозподілу пасажиропотоків по маршрутній мережі. На підставі даних про величину пасажиропотоків по кожному маршруту розраховують раціональну кількість транспортних засобів, техніко-економічні й техніко-експлуатаційні показники роботи на маршрутах.

Моделювання функціонування транспортної системи пасажирського сполучення відбувається шляхом зміни трас маршрутів у приміському сполученні й кількості транспортних засобів на них. Зміна цих параметрів дозволяє домогтися очікуваних показників ефективності функціонування транспортної системи пасажирського сполучення. Процес моделювання має ітераційний характер, що дозволяє використати його при розгляді нових альтернативних маршрутних мереж пасажирського сполучення регіону.

Підготовка і формування інформаційної бази моделювання передбачає збір вихідних даних про транспортну мережу приміського сполучення, характеристику дорожніх умов та транспортний попит на переміщення пасажирів.

Серед методів математичного опису транспортної мережі набули поширення наступні: 
1. Представлення мережі у вигляді сукупності вузлів, що мають свої координати, і так званих “бар'єрів”, що являють собою природні або штучні перешкоди (ріки, яри), проходження транспортних зв'язків між якими неможливо $[1,3,10]$. При такому методі опису мережі можливим $\epsilon$ визначення наближеної відстані між вузлами мережі з використанням коефіцієнта непрямолінійності транспортної мережі. Крім відстаней, на мережі можна розраховувати наближений час сполучення між вузлами виходячи 3 припущення, що швидкість транспортних засобів $\epsilon$ постійною величиною. Недоліком цього методу є неможливість застосування моделювання через відсутність інформації про поведінку об'єкта, тобто пасажиропотоку на окремих ділянках і у вузлах при вирішенні завдання розподілу пасажиропотоків по мережі. Поряд з цим перевагами даного методу є простота збору й невеликий обсяг вихідної інформації, а точність задовільна для виконання інженерних розрахунків.

2. Опис мережі, що грунтується на представленні ії у вигляді графа. Вузлами мережі $є$ населені пункти й пункти транспортного тяжіння, ланками - перегони між населеними пунктами транспортної мережі регіону. При цьому в топологічну схему входять тільки ті ділянки доріг, які за технічними умовами дозволяють рух транспортних засобів громадського користування. Цей метод набув великого поширення при вирішенні багатьох інженерних транспортних завдань завдяки високій точності. Вимоги до топологічної схеми:

1. Повинна бути виконана вимога про коректність подання реальних об’єктів точкою на графі транспортної мережі.

2. Рівень деталізації об’єктів, що входять у транспортну систему, обмежений можливістю одержання об'єктивної інформації про них.

Виділення виду перевезень, що цікавить нас, відбувається на рівні розробки топологічної схеми шляхом вибору відповідних об'єктів, призначення центрів і меж транспортних районів.

Величина пасажиропотоку за ланками мережі формується під дією транспортного попиту, найважливішим проявом якого $є$ обсяги відправлення і прибуття в транспортних вузлах мережі. Смність транспортних районів може бути визначена шляхом проведення натурних спостережень за пасажирообміном зупинних пунктів або 3 використанням анкетного методу обстеження пасажиропотоків. У даний час проведення повноцінного анкетного обстеження працездатного населення утруднене й практично не може бути використане для прогнозування ємностей транспортних районів. Для прогнозування ємності районів по відправленню треба використовувати статистичні дані про чисельність населення в транспортних районах (населених пунктах) і їх розподіл по території регіону.

Призначення границь і центрів транспортних районів (населених пунктів) при вирішенні завдань пасажирських перевезень у приміському сполученні повинне виконуватися таким чином, щоб всі переміщення всередині транспортного району здійснювалися пішки, всі переміщення між транспортними районами (населеними пунктами) зводилися до переміщень між їхніми центрами.

Матриця найкоротших відстаней може бути встановлена на підставі математичного опису транспортної мережі приміського сполучення. Для розрахунку матриці можна застосувати метод Флойда, який має нескладний алгоритм розрахунку й легко програмно реалізується $[1,2,10]$.

Останні дослідження вказують на те, що ряд вчених $[2-5,8]$ пропонують як основний критерій оцінки господарської діяльності використовувати показник “потенціал послуг”, який за своїм змістом представляє максимально можливий пасажирообіг із встановленим рівнем якості при повному використанні нормативної місткості рухомого складу протягом всього пробігу на маршруті. Відомі моделі $[1,5,8,10]$, в яких інтегровані в одну систему рівнянь транспортні витрати населення й витрати пасажирообслуговуючих підприємств. При цьому витрати виробника (перевізника)

$$
3_{B}=\left[C_{n o c m}\left(\frac{L_{M}}{v_{m}}+T_{n в}\right)+C_{3 M} L_{\mathcal{M}}\right] \frac{R_{O}}{Q_{i j}},
$$

де $C_{n o c m}$ - постійні витрати на одну годину роботи, грн/год.;

$C_{3 м}-$ змінні витрати на один кілометр пробігу, грн/км;

$L_{м}$ - довжина маршруту, км;

$R_{O}$ - кількість оборотних рейсів;

$T_{n \varepsilon}$ - сумарний час простою автобуса на зупинках за один рейс, год.;

$Q_{i j}$ - кількість пасажирів, перевезених між пунктами $i$ та $j$, пас.;

$v_{m}$ - технічна швидкість, км/год. 
Відносні витрати споживача (пасажира)

$$
3_{c}=C_{\text {Bid }}\left[\frac{k_{n}}{\delta}+\frac{a_{n} L_{M}}{N_{3 y n}}+k_{n e p}\left(\frac{I}{2}+\frac{l_{n}}{v_{c}}\right)\right] \text {, }
$$

де $C_{\text {вid }}$ - питома оцінка відносних витрат пасажира за час користування послугою, грн/год.;

$\delta$ - щільність маршрутної мережі, км/км²;

$k_{n}, a_{n}-$ константи, що визначають витрати часу на переміщення до (від) транспортної мережі, год/км

$N_{\text {зуn }}$ - кількість зупинних пунктів на маршруті;

$I$ - середній інтервал руху на ділянці маршруту, год.;

$l_{n}-$ середня дальність поїздки пасажирів на маршруті, км;

$k_{\text {nep }}-$ коефіцієнт пересадочності;

$v_{c}$ - швидкість сполучення, км/год.

На основі моделей $[3,6,8-10]$, побудована модель у структурі якої сполучені критерії оцінок якості транспортного обслуговування і перевезень, цільова функція набуває вигляду

$$
3=3_{6}+3_{c}+T \rightarrow \min .
$$

Однак мінімізація витрат приводить до системної помилки подвійного обліку втрат споживача як у вигляді фактора, що входить у тариф (T), так і при оцінці витрат виробника. Тому при модернізації цільової функції (8) замість тарифу вводиться фактор оцінки розміру субсидій, обумовлений, наприклад, за рекомендацією ЄС, для організації роботи громадського транспорту.

Після перетворення модель функціонування конкретного маршруту (8) з урахуванням (6) - (7) набуває вигляду

$$
3=3_{B}+3_{c}+S \rightarrow \min ,
$$

де $S$ - розмір адресних субсидій споживачу (виробнику).

Модель виду (9) побудована з використанням методів синергетичного опису функціонування транспортних систем, що розглядається як відкрита система. У результаті погодженої взаємодії спеціалізованих елементів (рухомий склад - транспортні шляхи - термінал) системи і зовнішнього середовища відбуваються постійні потокові й енергетичні обміни (включаючи виробник - послуга споживач), здійснення процесів яких організується методами логістики, що приводить до зростання ступеня її впорядкованості і зменшує ентропію.

Структура моделі (9) дозволяє досліджувати параметри, що визначають умови формування перевезень на конкретному напрямку (маршруті) і характеристики послуг, що узгоджуються 3 вимогами споживачів. На основі проведеного аналізу методів прогнозування потенціалу транспортних послуг встановлено, що найбільш прийнятною $є$ гравітаційна модель розрахунку. Але існуючі гравітаційні методи розрахунку потенціалу транспортних послуг мають ряд недоліків, що призводять до збільшення похибки розрахунку. Математичний опис надання послуг слід здійснити за реалізаціями транспортних процесів в елементах системи, між якими в зовнішньому середовищі виникають відносини, що виражаються закономірностями гравітаційного. Для усунення недоліків пропонується удосконалений метод прогнозування потенціалу транспортних послуг, що може бути застосований при моделюванні функціонування транспортної системи пасажирського сполучення.

Функцію розподілу переваг можна подати за допомогою критерію вибору способу переміщення. Вибираючи спосіб переміщення, суб'єкт мінімізує величину транзакційних витрат. Ця величина визначається множиною деяких факторів, а доцільність вибору того чи іншого фактора залежить від величини критерію вибору в кожній з доступних альтернатив. Чим менше критерій для визначеної альтернативи, тим вище імовірність ії вибору.

Необхідні умови вирішення завдань у загальному вигляді визначаються параметрами попереднього їх опису (геометричного положення точок), територіального розміщення вузлів, елементів системи на аналізованому ринку транспортного обслуговування, між якими формуються зв'язки різного роду, що вимагають кількісної оцінки реалізацій відповідно до висунутих потреб на транспортні послуги. Умови достатності встановлюють методи, алгоритм вирішення завдань 
визначення кількісних характеристик оптимальних транспортних процесів $\mathrm{i}$ зв’язків. Їх характеристики повинні враховувати нормативи обмежень забезпечення надійності, безпеки, доцільності, ефективності, інші специфічні умови функціонування систем. 3 цією метою в моделі (9) враховані фактори, що визначають індивідуальні переваги споживачів, для чого в гравітаційній моделі при оцінці потенціалу транспортних районів чисельністю населення $N_{i(j)}$ зміна об'ємів $d Q$ визначена зміною кількості жителів $d N$, рівня добробуту $d P$ і якості послуг $d Y$, обумовлені моделлю Бйоркмана $[3,5,7,12]$ :

$$
d Q=d N \cdot d P \cdot d Y^{2}
$$

Розрахункова формула для гравітаційної моделі, з урахуванням (10), має вигляд

$$
Q_{i j}=k_{i j} \frac{\left(N_{i}+d N_{i}\right)\left(N_{j}+d N_{j}\right)}{R_{i j}^{2}},
$$

де $R_{i j}$ - відстань від $i$-го пункту відправлення до $j$-го пункту прибуття.

Використовуючи модель Бйоркмана $[7,12]$, величину зміни чисельності населення визначаємо за формулою

$$
d N=\frac{d Q}{d P \cdot d Y^{2}}
$$

Підставивши формулу (7) у (6), одержимо вираз вигляду

$$
Q_{i j}=k_{i j} \frac{\left(N_{i}+\frac{d Q_{i}}{d P_{i} \cdot d Y_{i}^{2}}\right)\left(N_{j}+\frac{d Q_{j}}{d P_{j} \cdot d Y_{j}^{2}}\right)}{R_{i j}^{2}} .
$$

У результаті підстановки (13) у модель (9) маємо модель для визначення характеристик зміни попиту на ринку транспортних послуг на розглянутій території обслуговування.

Враховуючи дію факторів добробуту і якості послуг при оцінці зміни обсягів переміщень від $Q_{i j}$ до $Q_{i j} \pm d Q$, модель перерозподілу переваг набуває вигляду

$$
3=\left[\begin{array}{l}
{\left[C_{\text {nocm }}\left(\frac{L_{M}}{v_{m}}+T_{n в}\right)+C_{3 M} L_{M}\right] \frac{R_{o} \cdot R_{i j}^{2}}{k_{i j}\left(N_{i}+\frac{d Q_{i}}{d P_{i} \cdot d Y_{i}^{2}}\right)\left(N_{j}+\frac{d Q_{j}}{d P_{j} \cdot d Y_{j}^{2}}\right)}+} \\
+C_{\text {вid }}\left[\frac{k_{n}}{\delta}+\frac{a_{n} L_{M}}{N_{3 y n}}+k_{n e p}\left(\frac{I}{2}+\frac{l_{n}}{v_{c}}\right)\right]+S
\end{array}\right] .
$$

Модель вигляду (9), і остаточно (14) описує динаміку складних нелінійних процесів, параметри яких залежать від великої кількості факторів. Тому для вирішення завдань оптимізації необхідно застосовувати ітераційну процедуру [1, 3, 6-8, 10-12] послідовного поліпшення їі характеристик.

Сумарні характеристики попиту в окремих територіальних границях визначають ємність ринку транспортних послуг, що є базовим показником, який визначає умови виробництва і споживання транспортних послуг.

Параметри ємності ринку визначаються умовами формування міжрайонного балансу “відправлення - прибуття" пасажирів по всіх взаємодіючих вузлах зародження і погашення потреб у перевезеннях на розглянутій території. Така система знаходиться у фазовій рівновазі взаємодіючих транспортних пар за замкнутим часовим циклом переміщення пасажиропотоків. Транспортні пари 
утворюються 3 вузлів, відносно яких концентруються об'єкти обслуговування, розташовані в границях району тяжіння по трасах проходження маршрутів. Таким чином створюється система направлених пасажиропотоків, як показано на рис. 1.

Пасажиропотік у будь-якому перерізі напрямку перевезень (одного або декількох маршрутів) характеризує обсяг перевезень за певний період часу. Схема переміщення пасажиропотоків із загального вузла $F_{0}$ формується за напрямками $R_{i j}$, (див. рис. 1 , a).Схема включає послідовність переміщень у вузли $F_{1} \ldots F_{n-1}, F_{n}$, утворюючи сегмент за напрямком $R_{i j}$.

Обсяг пасажирів, які виїжджають, характеризується площею $F$ агрегатованого вузла обслуговування, щільністю $h_{F i}$ і транспортною рухомістю $N_{T(i)}$ населення, часткою перевезень, що здійснюються в даному напрямку $d \mu$. У загальному вигляді обсяг пасажирів, які виїжджають, за напрямками можна визначити $\quad[1, \quad 7, \quad 10] \quad 3$ виразу: $F h_{F} N_{T} d \mu=F_{1} h_{F 1} N_{T 1} d H_{1}+F_{2} h_{F 2} N_{T 2} d H_{2}+\ldots+F_{n} h_{F} N_{T_{n}} d H_{n}$. У такому випадку загальний обсяг перевезень за всіма напрямках буде визначатися за формулою

$$
\sum Q=\sum_{i=1}^{m} F_{i} h_{F i} N_{T_{i}} d H_{i}
$$

де $m$ - кількість напрямків (маршрутів) виїзду пасажирів.

Сукупність переміщень по всіх сегментах утворює загальну схему взаємодії об'єктів у транспортній системі (див. рис. 1, б), виходячи 3 виразів (11) - (13) і (14) - (15) при моделюванні функціонування маршрутної мережі приміського пасажирського сполучення. Коло в центрі позначає об'єкт тяжіння (обласний або районний центр). Кожен з напрямків виїзду пасажирів у приміському сполученні $I, I I, \ldots, N$ позначений окремим сегментом, що включає напрямки внутрішньообласних і приміського сполучень, $R_{\text {in }}$ - маршрути сполучення “центр - периферія” та “периферія - центр”.

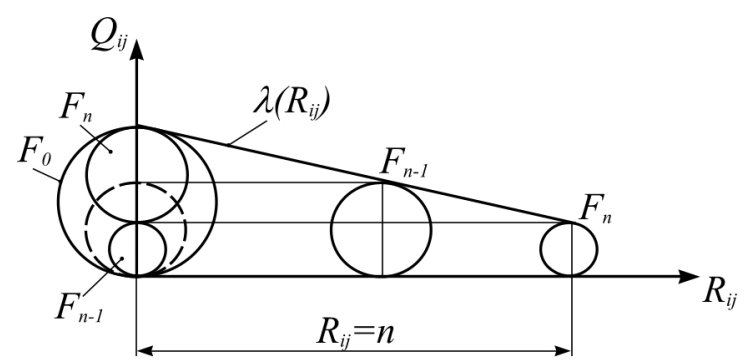

a)

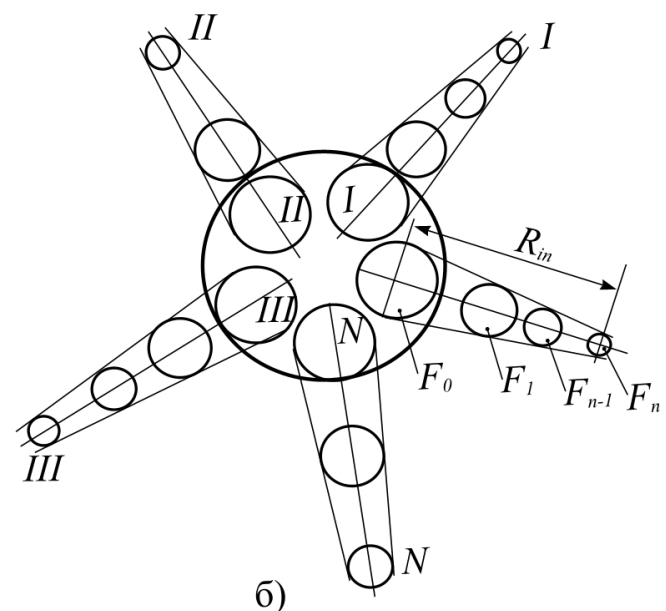

б)

Рисунок 1 - Схема взаємодії об’єктів у транспортній системі приміського пасажирського сполучення: a - переміщення пасажиропотоків із загального вузла, б - загальна схема взаємодії

Зміну попиту на маршрутах визначають транспортна рухомість населення $N_{T(i)}$ i частка перевезень, що здійснюються в даному напрямку $d н$ залежно від факторів Бйоркмана $(10),(12)[1,7$, 10-12].

Вводячи заміну $\delta$ на $L_{M M} / F$, де $L_{M M}$ - загальна довжина маршрутної мережі приміського сполучення на досліджуваній території (км), і з урахуванням (14) - (15) - замінивши $Q_{i j}$ на $h_{F} N_{T} F$, область транспортного обслуговування $(F)$ з моделі $(9)$ - (14), визначається новою цільовою функцією вигляду: 


$$
3=\left[\begin{array}{l}
{\left[C_{n o c m}\left(\frac{L_{M}}{v_{m}}+T_{n в}\right)+C_{3 M} L_{\mathcal{M}}\right] \frac{R_{o} \cdot R_{i j}^{2}}{h_{F} N_{T} F}+} \\
+C_{\text {вid }}\left[\frac{k_{n} F}{L_{F}}+\frac{a_{n} L_{M}}{N_{3 y n}}+k_{n e p}\left(\frac{I}{2}+\frac{l_{n}}{v_{c}}\right)\right]+S
\end{array}\right] .
$$

Площу транспортного обслуговування, що тяжіє до маршруту, знайдемо диференціюючи (16), i прирівнюючи вираз до нуля:

$$
\frac{d 3}{d F}=-\left[C_{\text {пост }}\left(\frac{L_{M}}{V_{m}}+T_{\text {Пв }}\right)+C_{3 м} L_{M}\right] \frac{R_{O}}{h_{F} N_{T} F^{2}}+C_{\text {від }} \frac{k_{n} F^{0}}{L_{M M}}=0 .
$$

Звідси

$$
F=\sqrt{\left[C_{n o c m}\left(\frac{L_{\mathcal{M}}}{v_{m}}+T_{n \beta}\right)+C_{3, M} L_{\mathcal{M}}\right] \frac{R_{O}}{h_{F} N_{T}} \cdot \frac{L_{M M}}{C_{6 i d} k_{n}}} .
$$

Визначальними факторами у формуванні величини площі транспортного обслуговування маршруту (18) є довжина маршруту сполучення $L_{M}$ і щільність населення на досліджуваній території. На етапі проектування нової маршрутної мережі пасажирського сполучення або дослідження функціонування існуючої необхідно мати інформацію про закономірності розподілу населення по території. Дослідження цієї закономірності вказують на значну нерівномірність розподілу населення. Результати розрахунків площі транспортного обслуговування маршруту у вигляді функції $F\left(L_{\mathcal{M}}, h_{F}\right)$ подані графічно на рис. 2.

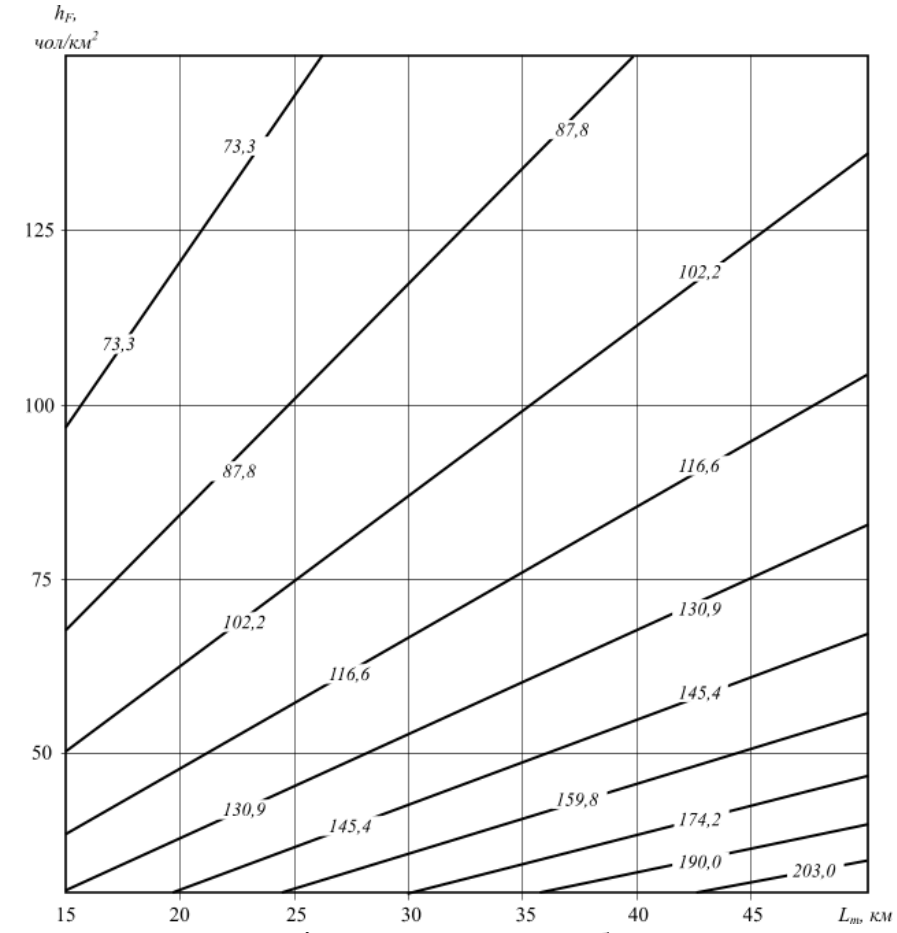

Рисунок 1 - Результати розрахунку площі транспортного обслуговування маршруту у вигляді функції

$$
F\left(L_{M}, h_{F}\right)
$$

Визначаючи параметр $F$ за всіма сегментами (маршрутами), уточнюємо ємність ринку по всьому регіону з виразу (15). Модель дозволяє провести сегментацію послуг з виразу (14) при зміні показників оцінки якості обслуговування для розробки еквівалентних заходів організації перевезень, що забезпечують найменші витрати при найбільш комфортних умовах обслуговування. Це 
відбувається за рахунок попереднього встановлення потенціалу послуг, визначення центрів зародження та погашення пасажиропотоків та їх величин. При цьому проектування маршрутної мережі або вдосконалення існуючої враховує такий важливий показник як провізна здатність, що повинна бути узгоджена з величиною пасажиропотоків та їх розподілом по мережі пасажирського сполучення.

\section{ОБГОВОРЕННЯ РЕЗУЛЬТАТІВ ДОСЛІДЖЕННЯ}

Відомі методики $[1,6-8]$ встановлення потенціалу транспортних послуг та формування матриць пасажирських кореспонденцій грунтуються на використанні гравітаційних моделей, та розроблені, в основному для дослідження взаємодії між транспортними районами міст.

Однак, для формування кореспонденцій у приміському сполученні, при взаємодії багатьох населених пунктів з різною щільністю населення, та віддаленістю від міста-центру, використання гравітаційних моделей ускладнене.

На відміну від існуючих методик $[1,3,4,6,7]$ визначення потенціалу транспортних послуг, запропонований метод 3 використанням площі транспортного обслуговування маршрутів простіший у практичному використанні та дає достатньо точні результати.

Населення вибирає центр тяжіння 3 урахуванням обмежень, накладених транспортною системою і на основі суб'єктивних міркувань про якість обслуговування. Розподіл транспортних зв'язків визначає поле розсіювання початкових і кінцевих пунктів переміщень, що в свою чергу, формує територіальну одиницю, яка обслуговується одним маршрутом, або системою маршрутів. Оскільки щільність населення у відношенні поселень неоднакова, то на їх множині виділяються територіальні одиниці, що складають зони обслуговування, та формують пасажиропотоки.

\section{ВИСНОВКИ}

Моделювання процесу функціонування транспортної системи пасажирського сполучення дозволяє провести оцінку ефективності на етапах проектування маршрутної мережі й вдосконалення діючої. Модель функціонування транспортної системи пасажирського сполучення умовно складається $з$ моделі транспортної мережі, моделі потреби в переміщеннях, моделі маршрутної мережі й моделі розподілу пасажиропотоків. Визначальним етапом у процесі моделювання транспортної системи пасажирського сполучення є модель маршрутної мережі, що являє собою траси маршрутів та їхніх провізних здатностей. Моделювання функціонування транспортної системи пасажирського сполучення відбувається шляхом зміни трас маршрутів у приміському сполученні й структури транспортних засобів на них. Зміна цих параметрів дозволяє домогтися очікуваних показників ефективності функціонування транспортної системи пасажирського сполучення.

Сумарні характеристики попиту в окремих територіальних границях визначають ємність ринку транспортних послуг, що є базовим показником, який визначає умови виробництва й споживання транспортних послуг. Параметри ємності ринку визначаються умовами формування міжрайонного балансу “відправлення - прибуття" пасажирів по всіх взаємодіючих вузлах зародження і погашення потреб у перевезеннях на розглянутій території. Визначальними факторами у формуванні величини площі транспортного обслуговування маршруту $є$ довжина маршруту сполучення і щільність населення на досліджуваній території.

\section{ПЕРЕЛІК ДЖЕРЕЛ ПОСИЛАННЯ}

1. Ефремов И.С., Кобозев В.М., Юдин В.А. Теория городских пассажирских перевозок. Москва: Высш. школа, 1980. 534 с.

2. Modeling of assessment of reliability transport systems / Yevhen Tkhoruk, Olena Kucher, Mykola Holotiuk, Mykhailo Krystopchuk, Oleg Tson // Proceedings of ICCPT 2019, May 28-29, 2019. — Tern. : TNTU, Scientific Publishing House "SciView", 2019. P. 204-210.

3. Кристопчук М. Є. Соціально-економічна ефективність пасажирської транспортної системи приміського сполучення : монографія / М. Є. Кристопчук. - Рівне: НУВГП, 2012. 158 с. / [Електронний ресурс]. - Режим доступу: http://ep3.nuwm.edu.ua/id/eprint/1645.

4. Cordera R, Sañudo R, dell'Olio L, Ibeas Á Trip distribution model for regional railway services considering spatial effects between stations // Transport Policy, vol. 67 (2018) pp. 77-84. doi: 10.1016/j.tranpol.2018.01.016.

5. Abdel-Aal M Calibrating a trip distribution gravity model stratified by the trip purposes for the city of Alexandria // Alexandria Engineering Journal, vol. 53, issue 3 (2014) pp. 677-689. doi: 10.1016/j.aej.2014.04.006

6. Kujala R, Weckström C, Mladenović M, Saramäki J. Travel times and transfers in public transport: Comprehensive accessibility analysis based on Pareto-optimal journeys // Computers, Environment and 
Urban Systems, vol. 67 (2018) pp. 41-54. doi: 10.1016/j.compenvurbsys.2017.08.012

7. Вильсон А. Дж. Энтропийные методы моделирования сложных систем. Перев. с англ. Москва: Наука, 1978. 248 с.

8. Михайлов А.С. Управление рынком перемещений городского населения - Алматы: НИЦ Гылым, 2003. 237 с.

9. Логистика: общественный пассажирский транспорт: Учебник для студентов экономических вузов / Под общ. ред. Л.Б. Миротина. Москва: Изд-во «Экзамен», 2003. 244 с.

10. Доля В. К. Дослідження транспортної мережі регіону методом побудови функції щільності населення / В. К. Доля, П. М. Грицюк, М. Є. Кристопчук // Коммунальное хозяйство городов. Научно-технический сборник. Вып. 69. Серия “Технические науки и архитектура”. Київ: “Техніка”, 2006. C. 205-211.

11. Cremer M., Keller H. A New Class of Dynamic Methods for the Identification of OriginDestination Flows // Transportation Research-B, 1987. Vol. 21(B). N2. P. 117 -132.

12. Peterson B.E. Calculation of capacity, queue length and delay in traffic facilities // Traffic Eng. and Contr., 1977. Vol. 18. - N 6. P. 310-312.

\section{REFERENCES}

1. Efremov, Y. S., Kobozev, V.M., \& Yudyn, V. A. (1980). Teoryia horodskykh passazhyrskykh perevozok, 534.

2. Tkhoruk Y., Kucher O., Holotiuk M., Krystopchuk M., \& Tson O. (2019). Modeling of assessment of reliability transport systems. Proceedings of ICCPT 2019, 204-210.

3. Krystopchuk, M. Ye. (2012). Sotsialno-ekonomichna efektyvnist pasazhyrskoi transportnoi systemy prymiskoho spoluchennia. Rivne, NUWM Publ, 158 p.. Available at: http://ep3.nuwm.edu.ua/id/eprint/1645.

4. Cordera R., Sañudo R., dell'Olio L., \& Ibeas Á. (2018). Trip distribution model for regional railway services considering spatial effects between stations. Transport Policy, 67, 77-84. doi: 10.1016/j.tranpol.2018.01.016.

5. Abdel-Aal M. (2014). Calibrating a trip distribution gravity model stratified by the trip purposes for the city of Alexandria. Alexandria Engineering Journal, 53, 677-689. doi: 10.1016/j.aej.2014.04.006

6. Kujala R., Weckström C., Mladenović M., \& Saramäki J. (2017). Travel times and transfers in public transport: Comprehensive accessibility analysis based on Pareto-optimal journeys. Computers, Environment and Urban Systems,67, 41-54. doi: 10.1016/j.compenvurbsys.2017.08.012

7. Vilson, A. Dzh. (1978). Entropiynyye metody modelirovaniya slozhnykh system [per. s angl.], 248.

8. Mikhaylov, A. S. (2003). Upravleniye rynkom peremeshcheniy gorodskogo naseleniya, 237.

9. Mirotin L. B. (2003). Logistika: obshchestvennyy passazhirskiy transport. 244.

10. Dolia, V. K., Hrytsiuk P. M., \& Krystopchuk M. Ye. (2006). Doslidzhennia transportnoi merezhi rehionu metodom pobudovy funktsii shchilnosti naselennia. Kommunalnoe khoziaistvo horodov, 69, 205211.

11. Cremer M., Keller H. A. (1987). New Class of Dynamic Methods for the Identification of OriginDestination Flows. Transportation Research-B, 21(B), 117-132.

12. Peterson B. E. (1977). Calculation of capacity, queue length and delay in traffic facilities. Traffic Engineering and Control, 18, 310-312.

\section{Khitrov, V. Soroka, M. Krystopchuk, S. Pashkevych. Model forming area of transport service routes of passenger traffic.}

One of the methods for assessing the efficiency of the passenger transport system of suburban communication during the design stage of the route network and improving its operation is the simulation of its operation. This process can be performed using a mathematical simulation apparatus.

The necessary prerequisites for solving the set tasks in general form are determined by the parameters of their preliminary description, territorial location of nodes, elements of the system in the considered market of transport services, between which links of various kinds are formed, requiring quantitative assessment of implementations in accordance with the put forward needs for transport services. Adequacy conditions establish methods and algorithm for solving problems of determining quantitative characteristics of optimal transport processes and connections. Their characteristics should take into account the standards of reliability, safety, expediency, efficiency, and other specific operating conditions of the systems.

The use of the latter to evaluate the consequences of changes in the route network of passenger traffic is of considerable interest for the following reasons: at present, a sufficiently complete mathematical 
apparatus is developed that allows to carry out the necessary modification of existing models, and takes into account the specifics of a specific route network; the use of mathematical models does not require significant resources and makes it easy to put them into practice with the use of computers, which allows for repeated analysis in the process of designing and operating the network; mathematical models, in contrast to full-scale modeling, measurement and statistical analysis of the parameters of a real route network of passenger traffic (if the route network is already designed and is in operation), allow to draw conclusions about the trends of network development, which is important in the study of the transport system passenger service.

The work proposes an improved method of forecasting the potential of transport services, which can be used in modeling the functioning of the passenger transport system.

Key words: passenger transport system, commuter service, transport service area, route network, transport services market.

ХІТРОВ Ігор Олександрович, кандидат технічних наук, доцент, доцент кафедри транспортних технологій i технічного сервісу, Національний університет водного господарства та природокористування, e-mail: i.o.khitrov@,nuwm.edu.ua; https://orcid.org/0000-0003-2310-1472;

СОРОКА Валерій Степанович, кандидат сільськогосподарських наук, доцент кафедри транспортних технологій і технічного сервісу, Національний університет водного господарства та природокористування, e-mail: v.s.soroka@nuwm.edu.ua;

КРИСТОПЧУК Михайло Свгенович, кандидат технічних наук, доцент, завідувач кафедри транспортних технологій і технічного сервісу, Національний університет водного господарства та природокористування, e-mail: m.ie.krystopchuk@nuwm.edu.ua; https://orcid.org/0000-0002-8701-4469;

ПАШКЕВИЧ Світлана Михайлівна, старший викладач кафедри транспортних технологій і технічного сервісу, Національний університет водного господарства та природокористування, е-таil: s.m.pashkevych@,nuwm.edu.ua. https://orcid.org/0000-0001-7667-8932.

Ihor KHITROV, $\mathrm{PhD}$, Associate Professor of the Transport Technology and Technical Service Department, National University of Water and Environmental Engineering, e-mail: i.o.khitrov@nuwm.edu.ua; https://orcid.org/0000-0003-2310-1472;

Valerii SOROKA, PhD, Associate Professor of the Transport Technology and Technical Service Department, National University of Water and Environmental Engineering, e-mail: v.s.soroka@,nuwm.edu.ua;

Mykhailo KRYSTOPCHUK, PhD., Associate Professor, Head of the Transport Technology and Technical Service Department, National University of Water and Environmental Engineering, e-mail: m.ie.krystopchuk@nuwm.edu.ua; https://orcid.org/0000-0002-8701-4469;

Svetlana PASHKEVYCH, Senior Lecturer of the Transport Technology and Technical Service Department, National University of Water and Environmental Engineering, e-mail: s.m.pashkevych@nuwm.edu.ua. https://orcid.org/0000-0001-7667-8932. 